\title{
Psychiatric and somatic health in relation to expereince of parental divorce in childhood
}

Teresia Ängarne-Lindberg and Marie Wadsby

\section{Linköping University Post Print}

N.B.: When citing this work, cite the original article.

Original Publication:

Teresia Ängarne-Lindberg and Marie Wadsby, Psychiatric and somatic health in relation to expereince of parental divorce in childhood, 2012, International Journal of Social Psychiatry, (58), 1, 16-25.

http://dx.doi.org/10.1177/0020764010382372

Copyright: SAGE Publications (UK and US)

http://www.uk.sagepub.com/

Postprint available at: Linköping University Electronic Press

http://urn.kb.se/resolve?urn=urn:nbn:se:liu:diva-54628 
Psychiatric and somatic health in relation to experience of parental divorce in childhood.

Running head: Parental divorce: psychiatric consultations and somatic health

Teresia Ängarne-Lindberg \& Marie Wadsby 


\begin{abstract}
Background: The outcome of studies about experience of parental divorce and effects on mental and physical health differs in result possibly caused by the use of different questionnaires and instruments, varying length of time since the divorce and divergent dropoff of participants. Aims: To study the presence of psychiatric records and number of diagnosed somatic and mental health care visits in a group of young adults with childhood experience of parental divorce in comparison to a group without this experience. Methods: The presence of a record at the public psychiatric clinics and ten years of administrative health care data (somatic and mental) was checked for both groups. Results: Significantly more persons from the divorce group occurred in child and adolescent psychiatric care, most pronounced women. However, no significant difference between the groups in number of persons seeking adult psychiatry, or in number of psychiatric consultations was present. Experience of parental divorce was not either found to be an indicator of larger somatic health problems. Conclusion experience of parental divorce in childhood is not an indicator of adult psychiatric or somatic need of care.
\end{abstract}

Keywords: somatic health; parental divorce; psychiatric records. 


\section{Introduction}

Parental divorce and its possible consequences is a life event that has been investigated by many researchers and interest in this subject remains strong since the divorce rate continues to be high although a slight decline has been observed in Sweden (SCB, 2007). Most studies on divorce assume divorce to be a stressful life event, an event to which both children and adults have to adjust (Amato, 2000). The accessible resources in this process of adjustment and circumstances round the divorce however show variation. The divorce literature offers many different theories as to why the psychological well-being of persons who experienced parental divorce in childhood differ (Amato, 2000; Hetherington \& Stanley-Hagan, 1999). Some research has pointed at theories such as crisis theory more directly connected to the divorce, while others focus on factors such as economic deprivation, family structure, and inter parental conflict, associated with or following divorce (Gähler, 1998). These and additional or other circumstances have been shown to contribute to a variety of problems such as alcohol abuse, smoking, behavioural/conduct problems, anxiety and depression (Amato, 2001; Harland et al., 2002; Lu et al., 2008; Rothman et al., 2008; Størksen et al., 2005).

Adverse childhood experiences such as parental divorce, or circumstances caused by the divorce, have besides or in addition to mental health problems been said to contribute to poorer physical health (Nunes-Costa et al., 2009). Published studies have pointed at larger risks for development of psychosomatic disorders, but also for development of cancer (Hemminki et al., 2006; Masuda et al., 2007). One study claim divorce to be a stressor responsible for maladjusted neuropsychobiological responses causing a decline in children's physical health (Nunes-Costa et al., 2009).

There is, however, other research that emphasizes the, in absolute terms, small average differences between persons with divorced and with continuously married parents. These results points at good mental health among a majority of persons with childhood experience 
of parental divorce (Amato, 2001; Chase-Lansdale et al., 1995; Gähler, 1998; ÄngarneLindberg \& Wadsby, 2009).

It could be established that the outcome of studies about experience of parental divorce and effects on mental health differ. The result of diverse studies relies in general on different questionnaires and instruments, and it is not unusual that the length of time that has passed since the divorce varies from study to study. These differences and the divergent drop out of participants are factors possibly influencing some of the differences in the outcome of studies (Afifi et al., 2009; Amato, 2001; Jónsson et al., 2000; Størksen et al.,2005; Størksen et al., 2006; Tyrka et al., 2008; Ängarne-Lindberg \& Wadsby, 2009). A homogeneous and systematic study of the matter in focus, with no drop of and similar length of time passed since the divorce might therefore add to research carried through earlier.

No study has, as far as we know, explored the presence of child and adolescent psychiatric and psychiatric records, and in addition to this, also number of diagnosed visits for somatic health problems including visits for mental and behavioural difficulties, in a group of young adults, with similar time passed since parental divorce in childhood, and also compared this with a group of young adults, with parents still married to each other. This in order to capture if persons with divorced parents are more affected by health problems, both psychiatric and somatic than persons with parents still married to each other.

\section{Aim}

The main purpose of the present study was therefore to investigate if the presence of a child and adolescent and/or a psychiatric record were more common among young adults (age 2738, age 7-18 at parental divorce, twenty years earlier), men and women respectively, with childhood experience of parental divorce, than among young adults (age 27-38) without this 
experience, this within public health care. If so, were there also a difference in given diagnoses and number of psychiatric consultations between the groups.

A second aim was to study whether possible overrepresentation of the divorce group in the group who sought health care could be connected to experienced parental divorce.

A third aim was to investigate if there was a difference between the divorce and the nondivorce group in number of persons seeking relief for different somatic health problems, and if in-patient and out-patient data for these people held additional information about mental and behavioural problems.

\section{Material and methods}

\section{Subjects}

The divorce group comprised all the men and women who were children between 0-18 years $(\mathrm{N}=239,119$ men and 120 women) when their parents filed for and completed a divorce at the district court in Linköping, Sweden during one year (July 1987 to June 1988), twenty years before the beginning of the study.

A comparison group $(\mathrm{N}=239,119$ men and 120 women) was formed with men and women whose parents were still married to each other. Persons of the same sex, born on the same, following or preceding day as the corresponding person in the divorce group, and who were living in the same area at the time for the start of the study comprised the non-divorce group. The participants in the comparison group were captured from the Swedish national population register, with due permission.

The court's judicial district includes Sweden's fifth largest city, some small densely populated areas and some rural areas, well representing the population in the country except for the biggest three city areas. 


\section{Procedure}

The first task was to determine if there was a record for each participant at the Child and Adolescent Psychiatric Clinic (up to 18 years of age, the general age limit for child and adolescent psychiatry in Sweden) and/or at the Psychiatric Clinic (18 years and older) at the University Hospital in Linköping serving the study region. This procedure was made with due permission from the current head physicians at these clinics and with approval from the Human Research Ethics Committee at Linköping University.

In those cases where a record was found, the diagnosis (plus possible divorce related difficulties or narratives), and if it was a consultation with psychiatrist, psychologist or social worker was noted.

In addition to these data, information was also obtained, with due permission, from the administrative database in the area. The administrative collection of data in the current county council started on January $1^{\text {st }}, 1998$. The data in the present study include all accessible data about the number of in- and out-patient health care visits, somatic diagnoses, and mental and behavioural diagnoses, during the period from the beginning of administrative data collection to the $30^{\text {th }}$ of December 2008, the end of the data collection of this study.

\section{Psychiatric care - Diagnoses according to DSM-IV}

All persons in the divorce and the non-divorce group with a psychiatric record were diagnosed according to DSM-IV, and the diagnoses were grouped according to the DSM-IV manual (DSM-IV, 1994). The adult psychiatric records all contained diagnoses, but most child and adolescent psychiatric records lacked a DSM-IV diagnosis due to accepted praxis within child psychiatric outpatient care. It was, however, fully possible for a practised child and adolescent psychiatrist to assign diagnoses according to the DSM-IV manual from the content in the records. The process of assigning diagnoses was blinded i.e. made by the 
practised child and adolescent psychiatrist without knowing the group possession (divorced or non-divorced parents) of each individual.

Somatic in- and outpatient health care - Diagnoses according to ICD-10

All recorded and diagnosed health care visits of persons in the divorce and the non-divorce group, were obtained from the administrative database, and they were then placed into groups according to the ICD-10 diagnosis and classification system (ICD-10, 1996).

\section{Ethical considerations}

The study was approved by The Human Research Ethics Committee at the Faculty of Health Sciences, Linköping University, (Dnr: 139-08). Permission for access to the psychiatric records was granted by the heads of the child/adolescent and adult psychiatric clinics at the University Hospital in Linköping, Sweden.

\section{Statistical analyses}

The results of the diagnoses and groups according to DSM-IV are presented in terms of numbers and percentages, the results of type of consultation are presented in terms of mean values and standard deviations (SD), and the result of diagnoses according to ICD-10 are presented in terms of the number of persons and the number of consultations. Differences between the divorce and the non-divorce groups as concerned the number of diagnoses according to DSM-IV were analysed using, Fisher's exact test. Differences between the groups as concerned the number of consultations were analysed using the Mann-Whitney $U$ test, and differences between groups as concerned number of persons in need of out-patient care were analysed using Chi-square or Fisher's exact test when appropriate. In all calculations of statistics, the SPSS package version 14.0 was used. 


\section{Results}

Presence of child and adolescent psychiatric contact and psychiatric contact

Both men $\left(x^{2}=11.20, P<0.001\right)$ and women $\left(x^{2}=28.49, P<0.001\right)$ in the divorce group had significantly more often had a child and adolescent psychiatric contact compared to the nondivorce group, $19.2 \%$ (14 men, and 32 women) had had this kind of contact compared to $2.1 \%$ (3 men, and 2 women) in the non-divorce group. Within the divorce group, it was noted that women more often than men had been given care $\left(x^{2}=4.37, P<0.05\right)$.

No significant difference was found between the divorce and the non-divorce group as concerned adult psychiatric contacts, even when gender was considered. In the divorce group, $6.7 \%$ (2.9\% of the men, $3.8 \%$ of the women) had had this kind of contact compared to $6.7 \%$ (1.7\% of the men, $5.0 \%$ of the women) in the non-divorce group (Figure 1).

\section{Figure 1 about here}

\section{Psychiatric records - diagnoses, number and type of treating consultations}

A significant difference was found between the divorce group and the non-divorce group in three groups of diagnoses, according to DSM-IV, in child and adolescent psychiatric care: 'disorders usually first diagnosed in infancy childhood or adolescence' $(P<0.05)$, 'mood disorders' $(P<0.05)$ and 'additional codes' $(P<0.001)$. All three diagnoses were more common in the divorce group than in the non-divorce group. The most common diagnoses in the diagnosis group 'additional groups' were to be preferentially referred to relational difficulties between family members and antisocial behaviour (Table 1).

Records from adult psychiatry showed no significant differences between the divorce and the non-divorce group as concerned psychiatric DSM-IV diagnoses (Table 2). 


\section{Table 1 and 2 about here}

There was no significant difference between the divorce and the non-divorce group as concerned the number or type of consultations, i.e. first or subsequent consultations and number of consultations with psychiatrist or psychologist/social worker. Similarly no difference was observed between gender neither within child and adolescent psychiatric care nor within adult psychiatric care (Table $3 a$ and $b$ ).

Seven persons (7\%) in the divorce group and two persons $(1 \%)$ in the non-divorce group had both a child and adolescent, and an adult psychiatry record (Table 1 and 2).

\section{Table $3 \mathrm{a}$ and $3 \mathrm{~b}$ about here}

\section{Somatic out- and in-patient health care - diagnoses and number of consultations}

The comparison between the divorce group and the non-divorce group in out-patient care showed a significant difference in five diagnosis groups according to ICD-10. More frequent in the non-divorce group were: 'neoplasms' $(P<0.01)$, 'endocrine, nutritional and metabolic diseases' $(P<0.05)$, 'diseases of the musculoskeletal system and connective tissue' $(P<$ 0.001), and 'factors influencing health status and contact with health services', (administrative contacts, medical examinations, observations or controls etc. $),(P<0.001)$. The divorce group showed a higher frequency than the non-divorce group only in the diagnosis group: 'injury, poisoning and certain other consequences of external causes' $(P<0.001)$, (Table 4$)$.

A significant difference between the divorce group and the non-divorce group in inpatient care was present only in the diagnosis group 'external causes of morbidity and mortality' $(P<0.05)$, the divorce group scoring lower (Table 5). 


\section{Mental and behavioural diagnoses within somatic out- and in--patient care}

No significant difference was observed in the number of out-patient or in-patient health care visits for 'mental and behavioural disorders' experienced by the divorce and the non-divorce group (Table 4). Thirty-eight persons (16\%) in the divorce group had an out-patient diagnosis for 'mental and behavioural disorders'. Twenty-three of those had either a child/adolescent or an adult psychiatric record, while 15 were diagnosed for out-patient care other than psychiatric. Thirty persons (13\%) in the non-divorce group had an out-patient diagnosis for 'mental and behavioural disorders'. Ten of those had an adult psychiatric record, while 20 were diagnosed for out-patient care other than psychiatric.

As concerns in-patient care, four persons $(1.7 \%)$ in the divorce group and four persons $(1.7 \%)$ in the non-divorce group were recorded as having been in patients to deal with 'mental and behavioural disorders, and all of these had an adult psychiatric record.

\section{Discussion}

The present study focused on the presence of records at the child/adolescent and adult psychiatric clinics, in a one-year population of individuals who were 0-18 years old when their parents divorced, 20 years before the start of the study. The frequency of occurrence of this group in these records was analysed and compared to the frequency of occurrence of persons from the non-divorce group. It was also investigated if a difference in somatic need of care existed between the groups, and if the records within out-patient and in-patient care held additional information about mental and behavioural difficulties in either group.

One of the most frequent child- and adolescent psychiatric diagnoses was 'mood disorders', diagnoses that might be reactions to disharmonious conditions in the family, as 
experience of parental divorce has been shown to be connected to emotional problems as anxiety and depression (Amato, 2001; Harland et al., 2002; Lu et al., 2008; Størksen et al., 2005; Tyrka et al., 2008). Also relational difficulties between family members under the heading 'additional codes' were more frequent in the divorce group, pointing towards visits to child and adolescent psychiatric care as being caused by possible divorce-related problems. There was, however, only one record that contained direct information about difficulties mentioned as divorce-difficulties. When it came to adult psychiatry no significant differences between groups, neither in number of persons with a psychiatric record or gender, nor in DSM-IV diagnoses, was found. This indicates, in the perspective from childhood to grown up age, a divorce between parents to play a subordinate role as concerns mental and behavioural problems in adulthood.

The results pointing at women as being more frequently occurring in the records of child and adolescent psychiatry points in the same direction as the results of other studies showing a poorer mental health among younger women with experience of parental divorce in childhood, a difference not as evident among women in older ages (Hurre et al., 2005; Pelkonen et al., 2008; Ängarne-Lindberg \& Wadsby, 2009). A possible explanation of the gender and age differences could be, as Cyranowski et al (2000) notes, a gender-linked vulnerability explaining why females, especially in combination with adolescent transitional difficulties, are more likely than males to become depressed when faced with negative life events, particularly life events with interpersonal consequences. Pelkonen et al (2008) point in their study at female gender as a risk factor for episodic but not for persistent depression, possibly indicating depression caused by a transitional crisis to be passing. It might be that this is the pattern that explains some of the differences in result between child/adolescent and adult psychiatry, and between genders in the present study. This however needs to be further investigated, and if so, is it determined by genetic differences or tradition, or maybe both? 
The non significant difference in the number of consultations between divorce and nondivorce group or between gender in either child/adolescent or adult psychiatry indicates no difference in magnitude of treatment between the divorce and the non-divorce group. If you are in need of psychiatric care the need is fairly equal and experience of parental divorce does not indicate a larger need of consultations (other than in number of persons in child and adolescent care). However, this outcome needs to be confirmed by studies based on larger groups than in the present study.

As concerns the somatic need of care, in-patient as well as out-patient, there were differences in number of persons seeking help in some of the groups of diagnoses (Table 4 and 5). The non-divorce group scored higher than the divorce group in five out of six diagnosis groups indicating people with experience of parental divorce in childhood not to be in more need of somatic health care than persons without this experience. There were, however, more persons in the divorce group who had been given an out-patient diagnosis under the group - 'Injury, poisoning and certain other consequences of external causes'. A possible explanation could be a more hazardous way of living, or risky health behaviour among children of divorce, something that has been confirmed in other studies (Hetherington \& Stanley-Hagan, 1999; Huurre et al., 2006). There were on the other hand significantly more persons in the non-divorce group getting an in-patient diagnosis under the group 'External causes of morbidity and mortality', indicating a limited (5 persons) but somewhat hazardous way of living also in the non-divorce group.

Circumstances that might have influenced the outcome of this study have to be put forward. Psychiatric help could have been received elsewhere than within the public health services, for example through private health care. However, in Sweden, most of the identified and severe cases will probably be referred to the psychiatric clinics, or will otherwise be recognized within other elements of the public health care system. Individuals in both groups 
have also presumably moved both in and out of the reception area during the twenty years that has passed. Earlier studies have pointed at a prevalence of psychiatric problems that causes obvious difficulties in 10-20 \% of all children and adolescents (Almqvist et al., 1999; Brandenburg, Friedman, \& Silver, 1990; Gustavsson, Lundin \& Svedin 2000; Offord, 1995; Rutter, 1989). The great difference between the divorce and the non-divorce group, $19.2 \%$ versus $2.1 \%$, might be explained by the fact that it was not known how many in the nondivorce group that grew up in the study area/reception area although most probably did. It is possible that children in the non-divorce group had a child psychiatric contact elsewhere. An absolutely complete and accurate picture of possible mental health problems among persons with experience of parental divorce in childhood is therefore difficult to obtain. The results however probably give a reasonably sound picture of the circumstances. Another limitation, possibly influencing the results, might be the lack of control of socio-economic status between the divorce and the non-divorce group. The risk for divorce has been shown to be twice as large if the partners have a low socioeconomic position (Statistics Sweden, 2009; Statistics Sweden, 1995), and it is possible that what some of the individuals in the divorce group have in common, beside divorce, is low socio-economic position which is a risk factor for poorer health (Socialstyrelsen, 2003). A report from the actual child- and adolescent psychiatric clinic based on a material analogous in time with the divorce of the parents however showed an equal distribution in number of psychiatric contacts between families with different socio-economic positions, comparable with the distribution in the country in its entirety (Gustavsson, Lundin \& Svedin, 2000). The results from an earlier study based on individuals from the same divorce and non-divorce groups showed the socioeconomic status among the parents at the time for the divorce to be similar to the general status in the study region (Wadsby \& Svedin, 1992), data not supporting low socio-economic position to be a 
major characteristic in the divorce group and a factor causing child- and adolescent psychiatric contacts.

The strength of the study is that it comprises all psychiatric records, for all men and women whose parents divorced in a specified region during one year, this with reservation for possible non public (private) health care given. The divorce and the non-divorce group are also equal in number of contributory persons. We have also, in comparison to other studies with results based on questionnaires, had the opportunity to through reading the records make an inventory on possible divorce related difficulties. By incorporating the database information about in-patient and out-patient care, even if only the last ten years were accessible, we increased the information to include also somatic health care visits and diagnoses, and mental and behavioural problems diagnosed within health care sectors other than the psychiatric.

To summarize; persons with divorced parents, and especially women, more often had a record within child and adolescent psychiatric care than did persons with non-divorced parents. The child and adolescent records were most likely to show the diagnoses 'mood disorder' and 'additional codes' where 'additional codes' included diagnoses such as relational difficulties between family members and antisocial behaviour. An indisputable connection to the divorce was, however, difficult to point at when reading the records. As for the rest, there were no significant differences found between the groups in number of persons with an adult psychiatric record, in number of psychiatric consultations, in number of somatic health consultations, or in number of mental and behavioural diagnoses within somatic care. I.e., experience of parental divorce was not found to be an indicator of greater likelihood of adult psychiatric or somatic health problems among the adult children of divorce. 
A focus for future research might be to further explore why there are so many more child psychiatric contacts among children of divorce compared to non-divorce children, but no differences when it comes to adult psychiatric contacts.

\section{Acknowledgement}

This study was supported by grants from 'Stiftelsen Clas Groschinskys Minnesfond' and the Swedish Council for Working Life and Social Research. 


\section{References}

Afifi, T.O., Boman J., Fleisher, W., Sareen, J. (2009) The relationship between child abuse, parental divorce, and life-time mental disorders and suicidality in nationally representative adult sample. Child Abuse \& Neglect, 33, 139-147.

Almqvist, F., Puura, K., Kumpulainen, K., Tuompo-Johansson, E., Henttonen, I., Huikko, E., Linna, S., Ikaheimo, K., Aronen, E., Katainen, S., Piha, J., Moilanen, I., Rasanen, E., \& Tamminen, T. (1999). Psychiatric disorders in 8-9-year-old children based on a diagnostic interview with the parents. European Child \& Adolescent Psychiatry, 8, 17-28.

Amato, P.R. (2000) The consequences of divorce for adults and children. Journal of Divorce \& Remarriage, 62, 1269-1287.

Amato, P.R. (2001) Children of divorce in the 1990:s an update of the Amato and Keith (1991) meta-analysis. Journal of Family Psychology, 15, 355-70.

Brandenburg, N. A., Friedman, R. M., Silver, S. E. (1990). The epidemiology of childhood psychiatric disorders: prevalence findings from recent studies. Journal of the American Academy of Child \& Adolescent Psychiatry, 29, 76-83.

Chase-Lansdale, P.L., Cherlin, A.J., Kiernan, K.E. (1995) The long-term effects of parental divorce on the mental health of young adults: a developmental perspective. Child Development, 66, 1614-1634.

Cyranowski, J.M., Frank, E.F., Young, E., Shear, K.M. (2000) Adolescent onset of the gender difference in lifetime rates of major depression. Archives of General Psychiatry, 57, 21-7. 
DSM-IV (1994) Diagnostic and statistical manual of mental disorders, $4^{\text {th }}$ edn. Washington, DC: American Psychiatric Association.

Gähler, M. (1998) Self-reported psychological well-being among adult children of divorce in Sweden. Acta Sociologica, 41, 209-225.

Gustavsson, P.A., Lundin, B., Svedin, C.G. (2000) Barn- och ungdomspsykiatriska vårdkontakter under uppväxten i fyra kommuner i centrala Östergötland. [Child- and adolescent psychiatric contacts during childhood and adolescence in four districts in central Östergötland.] Rapport nr 24. Avd. för barn- och ungdomspsykiatri, Hälsouniversitetet, Linköping [Report no 24. Division of child- and adolescent psychiatry, Faculty of Health Sciences, Linköping.]

Harland, P., Reineveld, S.A., Brugman, E., Verloove-Vanhorick, S.P., Verhulst, F.C. (2002) Family factors and life events as risk factors for behavioural and emotional problems in children. European Child and Adolescent Psychiatry, 11, 176-84.

Hemminki, K., Chen, B. (2006) Lifestyle and cancer: effect of parental divorce. European Journal of Cancer Prevention,15, 524-530.

Hetherington, E.M., Stanley-Hagan, M. (1999) The adjustment of children with divorced parents: a risk and resiliency perspective. Journal of Child Psychology and allied disciplines, 40, 129-140.

Huurre, T., Junkkari, H., Aro, H. (2006) Long-term Psychosocial effects of parental divorce: a follow-up study from adolescence to adulthood. European Archives of Psychiatry and Clinical Neuroscience, 256, 256-63. 
$\underline{\text { ICD-10 (1996). Klassifikation av sjukdomar och hälsoproblem } 1997 \text { [International }}$

Classification of Diseases and Related Health Problems, Tenth Revision]. Uppsala: Almqvist $\underline{\& \text { Wiksell. }}$

Jónsson, F.H., Njardvik, U., Ólafsdóttir, G., Grétarsson, S.J. (2000) Parental divorce: longterm effects on mental health, family relations and adult sexual behaviour. Scandinavian Journal of Psychology, 41,101-105.

Lu, W., Mueser, K.T., Rosenberg, S.D., Jankowski, M.K. (2008) Correlates of adverse childhood experiences among adults with severe mood disorders. Psychiatric Services, 59, 1018-26.

Masuda, A., Yamanaka, T., Hirasawa, T., Koga,Y., Minomo, R., Muemoto, T., Tei, C. (2007) Intra- and extra-familial adverse childhood experiences and a history of childhood psychosomatic disorders among Japanese university students. Biopsychosocial Medicine, 1, 9.

Nunes-Costa, R.A., Lamela, D.J., Figueiredo, B.F. (2009) Psychosocial adjustment and physical health in children of divorce. Journal of Pediatrics (Rio J), 85, 385-96.

Offord, D. R. (1995). Child psychiatric epidemiology: current status and future prospects. Canadian Journal of Psychiatry, 40, 284-288.

Pelkonen, M., Marttunen, M., Kaprio, J., Huurre, T., Aro, H. (2008) Adolescent risk factors for episodic and persistent depression in adulthood. A 16-year prospective follow-up study of adolescents. Journal of Affective Disorders, 106,123-31.

Rothman, E.F., Edwards, E.M., Heerent, T., Hingson, R.W. (2008) Adverse childhood experiences predict earlier age of drinking onset: results from a representative US sample of current or former drinkers. Pediatrics, 122, 298-304. 
Rutter, M. (1989). Isle of Wight revisited: twenty-five years of child psychiatric epidemiology. Journal of the American Academy of Child \& Adolescent Psychiatry, 28, 633653.

Sacco, K.A., Head, C.A., Vessicchio, J.C., Easton, C.J., Prigerson, H.G., GEORGE, T.P. (2007) Adverse childhood experiences, smoking, mental illness in adulthood: a preliminary study. Ann Clin Psychiatry, 19, 89-97.

Statistics Sweden (2007). Barn och deras familjer 2006 [Children and their families 2006]. Demografiska rapporter 2007: 4. Stockholm/Örebro: SCB.

Statistics Sweden (2009). Barn idag - En beskrivning av barns villkor med Barnkonventionen som utgångspunkt. [Children today - A description childrens’ conditions today with the Convention on the rights of the Child as starting-point.] Temarapport 2009: 2. Stockholm/Örebro: SCB.

Statistics Sweden (1995). Skilsmässor och separationer: bakgrund och utveckling. [Divorces and separations: background and development] Demografiska rapporter: 1995: 1. Stockholm: SCB

Socialstyrelsen (2003). Lägesrapport: Folhälsa och sociala förhållanden. [Report of the situation from The National Board of Health and Welfare: Public Health and Social conditions].

Størksen, I., Røysamb, E., Moum, T., Tambs, K.(2005) Adolescents with a childhood experience of parental divorce: a longitudinal study of mental health and adjustment. Journal of Adolescence, 28, 725-739. 
Størksen, I., Røysamb, E., Holmen, T.L., Tambs, K. (2006) Adolescent adjustment and wellbeing: effects of parental divorce and distress. Scandinavian Journal of Psychology, 47, 7584.

Tyrka, A.R., Wier, L., Price, L.H., Ross, N.S., Carpenter, L.L. (2008) Childhood parental loss and adult psychopathology: effects of loss characteristics and contextual factors. International Journal of Psychiatry in Medicine, 38, 329-44.14.

Wadsby, M., Svedin, C.G. (1992) Divorce: Different experiences of men and women. Family Practice, 9, 451-60.

Ängarne-Lindberg, T., Wadsby, M. (2009) Fifteen years after parental divorce: mental health and experienced life-events. Nordic Journal of Psychiatry, 63, 32-43. 


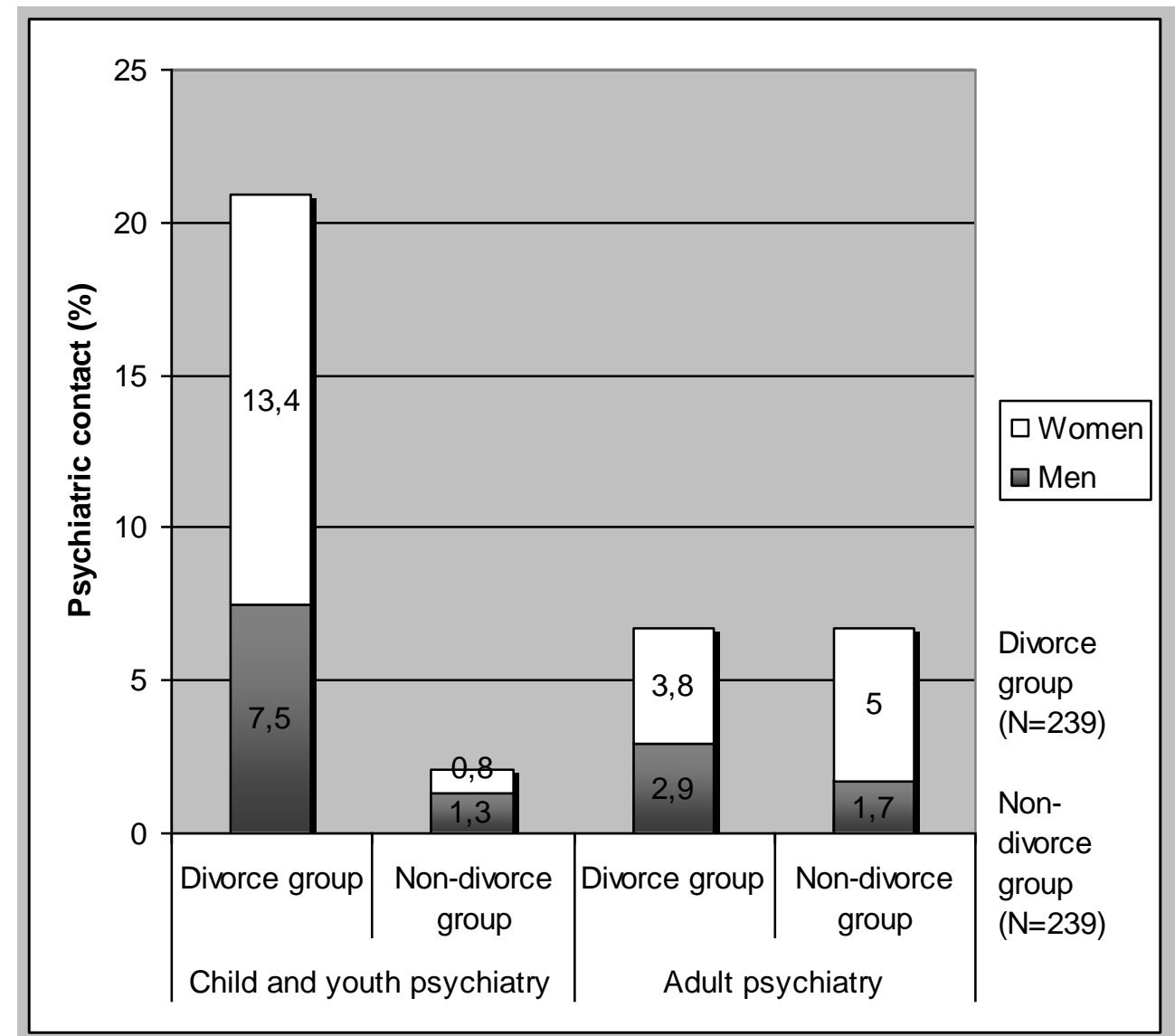

Fig. 1. Incidence of psychiatric contacts in the divorce and the non-divorce group. 
Table 1. Diagnoses according to DSM-IV: Child and adolescent psychiatry.

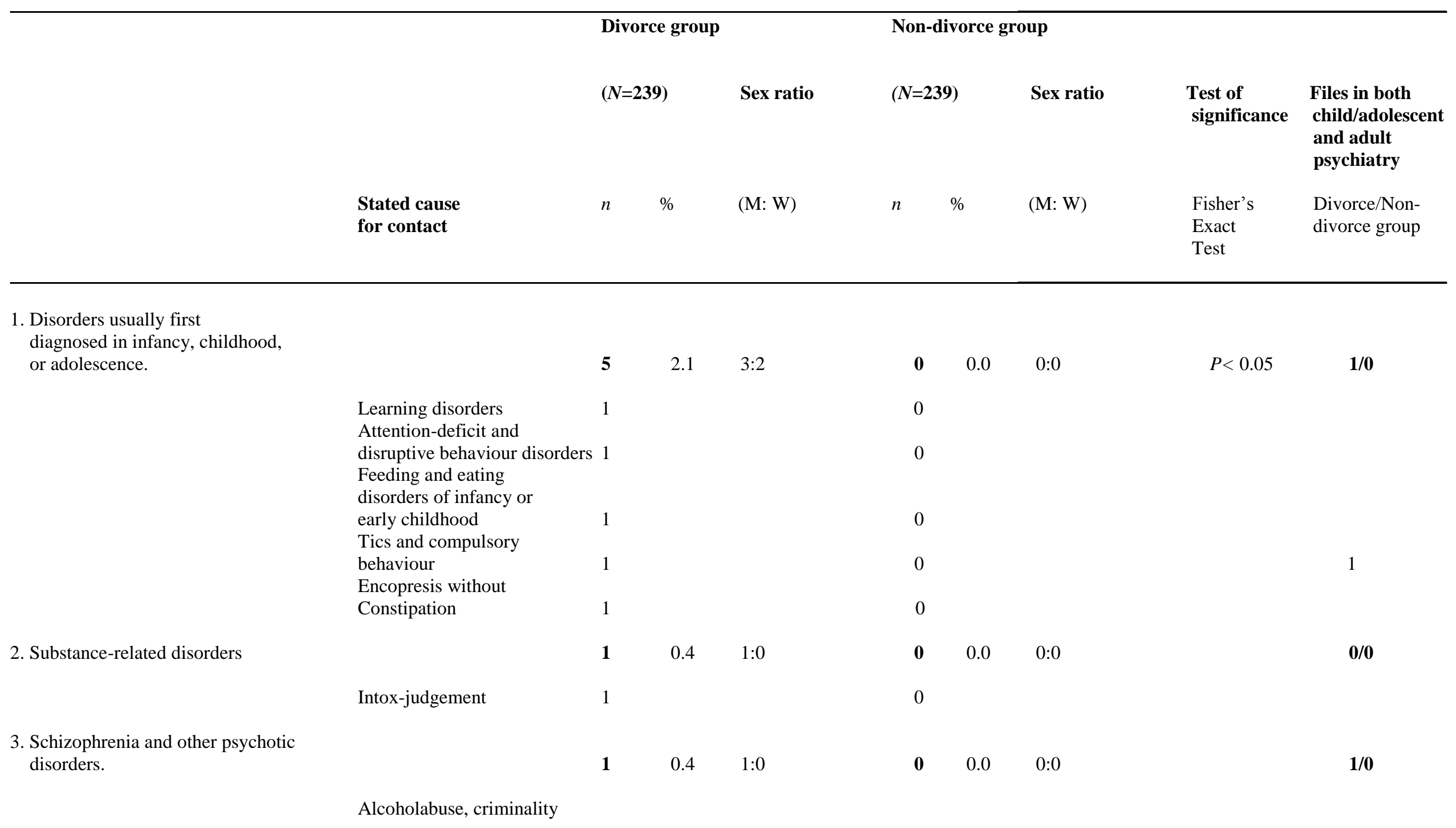


aggressiveness, voice-

hallucinations

4. Mood disorders

5. Anxiety disorders

6. Somatoform disorders

7. Eating disorders

8.Personality disorders

9. Additional codes
Moderate depression,

sadness, irritability

Depression, cutting-injuries,

recurrent thoughts of death

Depression disorder nos

Apathy and passivity

4
1
1
1

1
1
1

6

2.5

$1: 5$

Panic disorder

Specific phobia

Social phobia

Acute stress disorder

Sleeping disorder, fear of

death

Pain associated with psychological factors Eczema

Bulimia Nervosa

Antisocial behaviour physical abuse of child by adult

Relational difficulties 
between family members

Sexual abuse of child

Physical abuse of child

by another child

Relational problems
8

4

1

1

Missing files

*** $P<0.001$
0

0

0

$5 \quad 2.00 \quad 3: 2$

$7 / 2$ 
Table 2. Diagnoses according to DSM-IV: Adult psychiatry

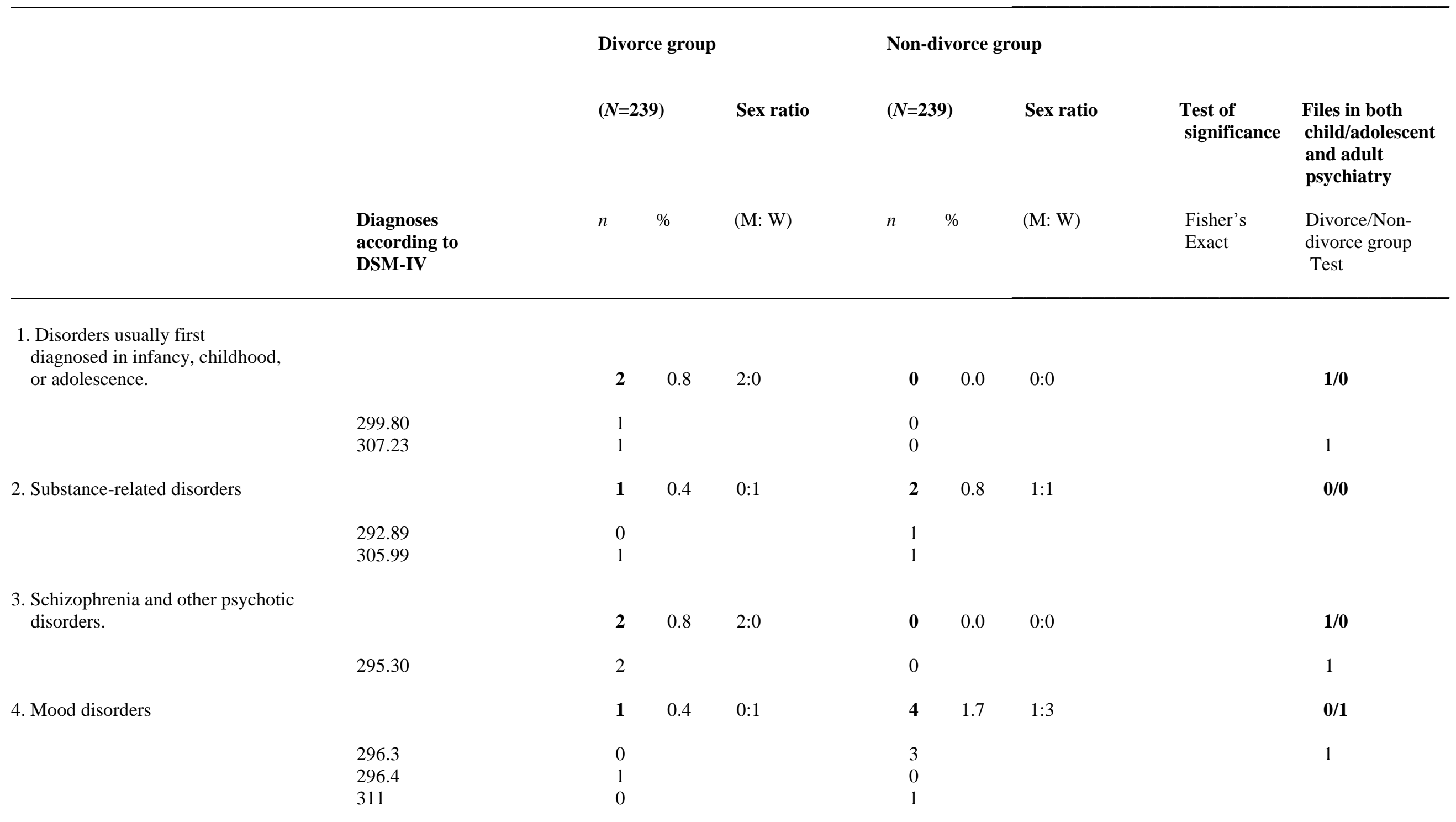


5. Anxiety disorders

308.3

309.81

6. Somatoform disorders

7 Eating disorders

307.51

8. Personality disorders

301.83

9. Additional codes

995.5

No diagnosis

Missing files

3
0
2

0

0

$20.8 \quad 0: 2$

2

$\begin{array}{lll}0 & 0.0 & 0: 0\end{array}$

1

0

0

0/0

0 $\quad 0.0 \quad 0: 0$

$2 / 0$

0

2

0/0

0

$\begin{array}{lll}1 & 0.4 & 0: 1\end{array}$

1

$1 \quad 0.4 \quad 0: 1$

$1 \quad 0.4 \quad 0: 1$

$1 / 1$

1

$1 \quad 0.4 \quad 0: 1$

1/0

$\begin{array}{lll}1 & 0.4 & 1: 0\end{array}$

$\begin{array}{lll}4 & 1.7 & 1: 3\end{array}$

$20.8 \quad 1: 1$

$16 \quad 6.7 \quad 4: 12$

$7 / 2$

$6.5 \quad 7: 9$

$7: 9$


Table 3a. Type of consultation among persons in divorce group and non-divorce group with a record in child and adolescent psychiatry.

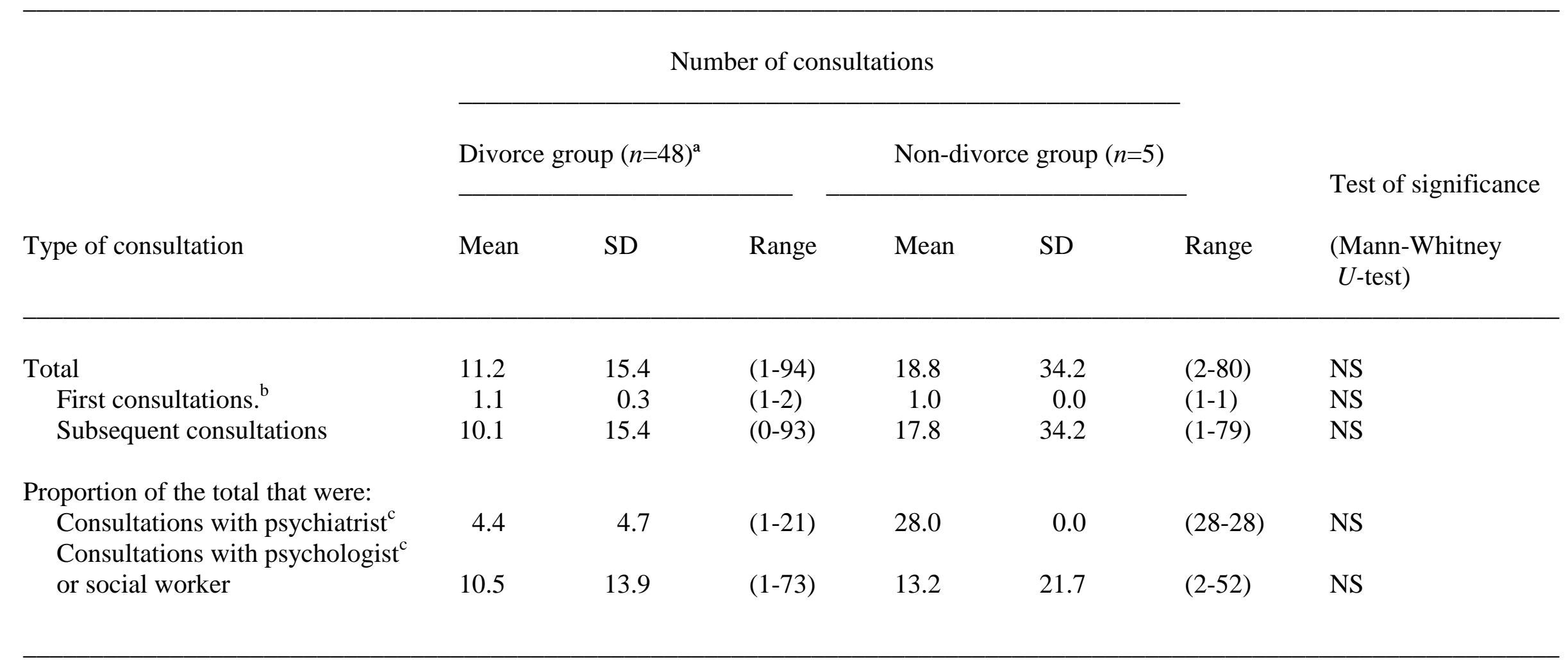

\footnotetext{
a files are missing.

${ }^{\mathrm{b}}$ First visit is recorded when $>18$ months have elapsed since last consultation.

${ }^{\mathrm{c}}$ One person can consult both psychiatrist and psychologist/social worker.
} 
Table 3b.Type of consultation among persons in divorce group and non-divorce group with record in adult psychiatry.

\begin{tabular}{|c|c|c|c|c|c|c|c|}
\hline \multirow[b]{3}{*}{ Type of consultation } & \multicolumn{5}{|c|}{ Number of consultations } & \multirow[b]{3}{*}{ Range } & \multirow{3}{*}{$\begin{array}{l}\text { Test of significance } \\
\text { (Mann-Whitney } \\
U \text {-test) }\end{array}$} \\
\hline & \multicolumn{3}{|c|}{ Divorce group $(n=14)^{\mathbf{a}}$} & \multicolumn{2}{|c|}{ Non-divorce group $(n=12)^{\mathrm{b}}$} & & \\
\hline & Mean & $\mathrm{SD}$ & Range & Mean & $\mathrm{SD}$ & & \\
\hline Total & 25.4 & 29.6 & $(1-107)$ & 15.4 & 11.6 & $(1-34)$ & NS \\
\hline First consultations ${ }^{c}$ & 1.2 & 0.4 & $(1-2)$ & 1.1 & 0.3 & $(1-2)$ & NS \\
\hline Subsequent consultations & 24.1 & 29.6 & $(0-106)$ & 14.1 & 11.7 & $(0-33)$ & NS \\
\hline $\begin{array}{l}\text { Proportion of the total that were: } \\
\text { Consultations with psychiatrist }{ }^{\mathrm{d}} \\
\text { Consultations with psychologist } \\
\text { or social worker }\end{array}$ & 14.3 & 27.7 & $(1-107)$ & 4.7 & 3.4 & $(2-12)$ & NS \\
\hline
\end{tabular}

a 2 files are missing.

${ }^{\mathrm{b}} 4$ files are missing.

${ }^{\mathrm{c}}$ First visit is recorded when $>18$ months have elapsed since last consultation.

${ }^{\mathrm{d}}$ One person can consult both psychiatrist and psychologist/social worker. 
Table 4. Diagnoses according to ICD-10. Number of persons in need of out-patient care, and number of occasions.

$\begin{array}{llll}\begin{array}{l}\text { Classification } \\ \text { according to }\end{array} & \text { Divorce group } & \text { Non-divorce group } & \text { Test of significance } \\ \text { ICD-10 } & (\mathrm{N}=239) & (\mathrm{N}=239) & \text { Number of } \\ & \text { Number of } & \text { phi²/Fisher's exact test } \\ & \text { persons (occasions): } & \text { persons (occasions): }\end{array}$

1. Certain infectious and parasitic diseases

2. Neoplasms

3. Diseases of the blood and blood-forming organs and certain disorders involving the immune mechanism

4. Endocrine, nutritional and metabolic diseases

5. Mental and behavioural disorders

6 . Diseases of the nervous system

7. Diseases of the eye and adnexa

8. Diseases of the ear and mastoid process

9. Diseases of the circulatory system

10. Diseases of the respiratory system

11. Diseases of the digestive system

12. Diseases of the skin and subcutaneous tissue

13. Diseases of the musculoskeletal system and connective tissue

14. Diseases of the genitourinary system

15. Pregnancy, childbirth and the puerperium

16. Certain conditions originating in the perinatal Period

17. Congenital malformations, deformations and chromosomal abnormalities

$51(87) \quad 51(64)$

$27(43) \quad 49(64)$

$p<0.01$

2 (3)

3 (3)

$38(86)$

15 (18)

$19(27)$

$30(47)$

10 (11)

120 (238)

39 (74)

65 (102)

2 (3)

$12(20)$

30 (69)

17 (19)

24 (39)

28 (47)

16 (20)

131 (255)

46 (76)

84 (129)

84 (184)

85 (133)

$142(150)$

88 (129)

44 (76)

32 ( 60)

$0(0)$

$0(0)$

$6(7)$

3 (3) 
18. Symptoms, signs and abnormal clinical and laboratory findings, not elsewhere classified

19. Injury, poisoning and certain other consequences of external causes

20. External causes of morbidity and mortality

21. Factors influencing health status and contact with health services 
Table 5. Diagnoses according to ICD-10. Number of persons in need of institutional care (in patient hospital treatment), and number of occasions .

\section{Classification according to} ICD-10

\section{Divorce group \\ Non-divorce group}

$(n=239)$

Number of:

persons (occasions) $(n=239)$

Number of:

persons (occasions)
1. Certain infectious and parasitic diseases

2. Neoplasms

3. Diseases of the blood and blood-forming organs and certain disorders involving the immune mechanism

4. Endocrine, nutritional and metabolic diseases

5. Mental and behavioural disorders

6. Diseases of the nervous system

7. Diseases of the eye and adnexa

8. Diseases of the ear and mastoid process

9. Diseases of the circulatory system

10. Diseases of the respiratory system

11. Diseases of the digestive system

12. Diseases of the skin and subcutaneous tissue

13. Diseases of the musculoskeletal system and connective tissue

14. Diseases of the genitourinary system

15. Pregnancy, childbirth and the puerperium

16. Certain conditions originating in the perinatal Period

17. Congenital malformations, deformations and

$\begin{array}{cc}6(6) & 7(7) \\ 2(2) & 4(4) \\ & \\ 0(0) & 0(0) \\ 0(0) & 3(3) \\ 4(6) & 4(8) \\ 2(2) & 4(4) \\ 0(0) & 0(0) \\ 0(0) & 0(0) \\ 1(1) & 1(1) \\ 5(6) & 10(11) \\ 12(16) & 14(14) \\ 0(0) & 2(2) \\ & \\ 5(5) & 1(1) \\ 1(1) & 5(5) \\ 42(64) & 49(78)\end{array}$

$0(0)$
$0(0)$

(4)

$0(0)$

$1(1)$

$10(11)$

4 (14)

$1(1)$

$49(78)$
Test of significance $\mathrm{Chi}^{2} /$ Fisher's exact test 
chromosomal abnormalities

18. Symptoms, signs and abnormal clinical and laboratory findings, not elsewhere classified

19. Injury, poisoning and certain other consequences of external causes

20. External causes of morbidity and mortality

21. Factors influencing health status and contact with health services
$1(1)$

$0(0)$

$10(10)$

$12(12)$

$16(16)$

$0(0)$

$16(21)$

$5(5)$

$p<0.05$

$6(6)$

$6(6)$ 


\section{Corresponding author:}

Teresia Ängarne-Lindberg

Ph.D.

IKE/Child and Adolescent Psychiatry

Faculty of Health Sciences

SE-581 85 Linköping

Sweden

e-mail: teresia.angarne-lindberg@liu.se

phone +46101034213

fax $\quad+46101034234$

Marie Wadsby

Associate Professor

IKE/Child and Adolescent Psychiatry

Faculty of Health Sciences

SE-581 85 Linköping

Sweden

e-mail: Marie.Wadsby@liu.se

phone: +46101034208

fax: $\quad+46101034234$ 